\title{
Changes in LH pulse frequency and amplitude in intact mares during the transition into the breeding season
}

\author{
B. P. Fitzgerald, K. J. Affleck, S. P. Barrows, W. L. Murdoch, K. B. Barker* \\ and R. G. Loy
}

Department of Veterinary Science and ${ }^{*}$ Agricultural Statistics, University of Kentucky, Lexington, KY 40546-0076, U.S.A.

\begin{abstract}
Summary. Two groups of mares were exposed to an abrupt, artificial increase or a natural increase in daylength. In both groups, mean LH pulse frequency increased with time of year and was accompanied by a reciprocal decrease in $\mathrm{LH}$ pulse amplitude. A non-pulsatile pattern of LH secretion was observed in some mares sampled close to the day of ovulation. Maximum mean LH pulse frequency and the onset of the breeding season occurred earlier in those mares exposed to an abrupt artificial increase in daylength. In blood samples collected frequently, mean serum LH concentrations increased in relation to time of year. However, during 60 days before ovulation, when LH pulse frequency increased, mean daily serum $\mathrm{LH}$ values only increased on Day -3 before ovulation. The magnitude of the periovulatory LH rise was greater before the second than the first ovulation of the breeding season. These results support the hypothesis that, in the mare, a photoperiod-induced seasonal alteration in LH pulse frequency and/or amplitude may play a role in the onset of the breeding season.
\end{abstract}

\section{Introduction}

In many mammalian species the secretion of luteinizing hormone (LH) is pulsatile (Dierschke et al., 1970; Yen et al., 1974; Baird, 1978; Rahe et al., 1980; Gallo, 1981). In the mare, the secretion of LH is also pulsatile (Fitzgerald et al., 1983, 1985) although the detection of pulsatile LH secretion in jugular venous blood appears limited to those experimental or physiological conditions when the frequency of LH pulses might be anticipated to be low. For example, in ovariectomized mares a pulsatile pattern of LH secretion can be identified during the spring months when serum LH concentrations are low or gradually rising in association with an increase in daylength. However, during the summer months, when serum LH values are maximally elevated in this long-day breeder, discrete LH pulses can no longer be demonstrated (Garcia et al., 1979; Fitzgerald et al., 1983). Similarly, in intact mares a pulsatile pattern of LH secretion is evident during the luteal phase of the oestrous cycle (Fitzgerald et al., 1985) when progesterone exerts a negative feedback action on LH secretion (Ginther, 1979). However, before ovulation, when ovarian negative feedback effects on the hypothalamus-pituitary system are absent or minimal (Ginther, 1979), the pattern of LH secretion is non-pulsatile (Fitzgerald et al., 1985).

In intact mares, the onset of the breeding season occurs in response to an increase in daylength and can be advanced by exposure of anoestrous mares to an artificial increase in daylength (Sharp \& Ginther, 1975). The first ovulation of the breeding season is preceded by a period of prolonged oestrous behaviour accompanied by increased ovarian follicular development. Although LH has been implicated in both follicular development and ovulation of the mare (Pineda \& Ginther, 1972; Licht et al., 1979), serum LH remains at low levels in blood samples collected 2-3 times per week, until 6-7 days before the first ovulation of the breeding season (Freedman et al., 1979; Turner et al., 1979). During this 6-7-day period before ovulation, serum LH concentrations gradually increase to a maximum within 1 day after ovulation. 
Based on the consideration that during the spring months the pattern of LH secretion in ovariectomized mares is pulsatile and that mean serum LH concentrations and LH pulse frequency both increase over a prolonged time period, the absence of a measurable increase in serum LH values in intact mares until 6-7 days before ovulation may reflect infrequent collection of blood samples. The purpose of the present study, therefore, was to investigate this possibility in two groups of intact anoestrous mares in which the onset of the breeding season occurred either in response to an abrupt, artificial increase in daylength or a gradual, natural increase in photoperiod. An additional and related objective was to characterize alterations in LH pulse frequency and amplitude in relation to the occurrence of the onset of oestrous cycles.

\section{Materials and Methods}

Animals and treatments. Two groups of anoestrous horse mares were maintained outdoors on pasture, except during sampling periods or experimental procedures, when they were housed in stalls. All mares received oats and hay daily and water was freely available.

Beginning I December, 4 mares (Group 1) were exposed to an abrupt artifical increase in daylength to advance the onset of the breeding season. Mares were kept in stalls between 15:00 and 07:00 $\mathrm{h}$ each day and exposed to artificial lighting between 16:00 and 23:00 h, thereby extending daylength to at least $16 \mathrm{~h}$ light per day. The remaining 5 mares (Group 2) were maintained in natural photoperiodic conditions for Lexington $\left(38^{\circ} 2^{\prime} \mathrm{N}\right)$.

Follicular development, oestrus and ovulation. Follicular development was assessed by palpation of the ovaries per rectum at least every 3 days, or daily after identification of a follicle $25 \mathrm{~mm}$ in diameter or larger. The occurrence of ovulation was indicated by the collapse of a follicle. Oestrus was monitored by teasing daily with a stallion.

Collection of blood samples. Blood samples $(5 \mathrm{ml})$ were collected daily at $09: 00 \mathrm{~h}$ by jugular venepuncture beginning on 30 December (Group 1) or 2 February (Group 2), until each mare had completed an oestrous cycle. Changes in pulsatile LH secretion were determined in additional samples collected via an intravenous catheter. For Group 1 mares, blood samples $(5 \mathrm{ml})$ were collected every $15 \mathrm{~min}$ for 24 -h periods before ( 15 November), on the day of $(1$ December) and 2 weeks after (16 December) exposure to an abrupt increase in daylength. Thereafter, it was anticipated that LH pulse frequency might increase and therefore the duration of frequent sample collection (every $15 \mathrm{~min}$ ) was reduced to $12 \mathrm{~h}$ and performed every 2 weeks until ovulation. Frequent samples were also collected for $24 \mathrm{~h}$ from mares of Group 2 on 12 December and 5 January; thereafter, samples were collected for $12 \mathrm{~h}$ every 2 weeks until ovulation. All frequent sample collection periods began at 12:00 h. During the hours of darkness, blood samples were collected with the aid of a dim red light. The cannula was inserted $30 \mathrm{~min}$ before sample collection and maintained patent by flushing with saline $(9 \mathrm{~g} \mathrm{NaCl} / \mathrm{l})$. At each sample withdrawal, the first $1 \mathrm{ml}$ was discarded and a further $5 \mathrm{ml}$ collected. All blood samples were kept overnight at $4^{\circ} \mathrm{C}$. Serum was collected and stored frozen until assayed.

Radioimmunoassay of $L H$. Luteinizing hormone concentrations were measured in duplicate $10-200 \mu$ samples of serum using a radioimmunoassay procedure described previously (Loy et al., 1982). A horse pituitary LH preparation (E98A), kindly supplied by Dr H. Papkoff, was used as standard. This preparation had 2.97 times the activity of NIH-LH-S1 according to the ovarian ascorbic acid depletion assay (Licht et al., 1979). The sensitivity of the radioimmunoassay was $0.014 \mathrm{ng} /$ tube. Intra-assay and interassay coefficients of variation were 10 and $13 \%$ respectively for a serum pool that produced a $50 \%$ inhibition of binding of radiolabelled LH to antibody ( 30 assays).

Analysis of data. Changes in mean serum LH concentrations before ovulation, in samples collected daily, were analysed using a repeated measures analysis of variance. Multiple comparisons using the least-squares means (SAS User's Guide, 1985) were used to identify the timing of the onset of the periovulatory increase in serum LH values, relative to ovulation. Additionally, in both groups of mares, orthogonal contrasts were used to test for linear, quadratic and cubic effects of the periovulatory rise in serum LH concentrations during a 10-day period before the first and second ovulations of the breeding season.

The occurrence of an LH pulse was identified as described previously (Fitzgerald et al., 1985). Changes in $\mathrm{LH}$ pulse frequency, with respect to time of year and occurrence of ovulation, were tested by $\chi^{2}$ analyses. In the case of days before ovulation, data were blocked into sampling intervals of 10 days. This procedure resulted in 7 time periods (blocks) ranging from 10-0 days to $>60$ days before ovulation. Appropriate contrasts were used to test for differences between blocks. Since the duration of frequent sample collection was not constant, changes in LH pulse frequency were statistically analysed for blood samples collected between 12:00 and 24:00 $\mathrm{h}$.

Comparison of mean serum LH concentrations determined in blood samples collected daily or in periods of frequent sample collection during 60 days before ovulation was made by analysis of variance. The relationship between LH pulse frequency and amplitude was determined by regression analysis. Values are presented as mean \pm s.e.m. 


\section{Results}

\section{Oestrus, follicular development and occurrence of ovulation}

Ovulation occurred earlier $(P<0.01)$ in Group 1 than Group 2 mares $(65.7 \pm 6.8 v s$ $135.6 \pm 3 \cdot 7$ days after 1 December), corresponding to 4 February and 14 April, respectively.

In all mares, ovulation was preceded by prolonged oestrous behaviour averaging 25 and 50 days in Groups 1 and 2, respectively. In both groups, the period of prolonged oestrus included days when mares were unresponsive or passive towards the teaser stallion. Therefore, this apparent difference in duration of oestrus between the respective groups was not statistically evaluated.

The occurrence of oestrus was generally accompanied by an increase in the size of the ovaries although, initially, follicles could not be palpated. Subsequently, palpable follicles were recorded and in 3 and 4 mares in Groups 1 and 2, respectively 1 or 2 follicles reached preovulatory dimensions ( $\geq 35 \mathrm{~mm}$ diameter) but regressed before development of a similar large follicle that ovulated. In the remaining 2 mares, the development of a smaller follicle ( $\leq 25 \mathrm{~mm}$ diameter) was recorded before identification of the preovulatory follicle.

\section{Daily serum LH profile before the first ovulation of the breeding season}

In 4 mares (Group 1) exposed to an abrupt artificial increase in daylength, beginning 1 December, mean serum LH concentrations in samples collected daily for 24 days before ovulation remained $<1 \mathrm{ng} / \mathrm{ml}$ until Day -3 . Thereafter, serum LH increased $(P<0.001)$ to a maximum level of $3.59 \pm 0.70 \mathrm{ng} / \mathrm{ml}$ on Day -1 before ovulation (Fig. 1, upper panel). Similarly, in 5 mares (Group 2) exposed to natural photoperiodic conditions and from which samples were collected for 60 days before ovulation, mean serum LH rose $(P<0.001)$ on Day -3 to attain $3.55 \pm 0.98 \mathrm{ng} / \mathrm{ml}$ on the day of ovulation. Although during a 24-day period before ovulation serum $\mathrm{LH}$ concentrations were not different $(P>0.05)$ between groups and in both the first increase in serum LH levels occurred 3 days before ovulation, the periovulatory $\mathrm{LH}$ rise during a 10 -day period was linear $(P<0.01)$ for Group 2 whereas in Group 1 serum LH increased abruptly on Day -3 before ovulation and therefore the periovulatory LH rise showed a significant $(P<0.01)$ quadratic effect.

Changes in mean serum $\mathrm{LH}$ concentrations and the pattern of $\mathrm{LH}$ secretion established from frequent collection of blood samples are presented below for each group both in relation to the time of year and in combination after normalization of the data with respect to the time of occurrence of ovulation.

\section{$L H$ pattern in relation to time of year}

In both groups, a minor but significant $(P<0.05)$ increase in mean serum LH values was observed in relation to time of year. With the exception of one mare in late April (Group 2), in which the day of frequent sample collection coincided with ovulation, mean serum LH concentrations remained $<1 \mathrm{ng} / \mathrm{ml}$ (Table 1$)$.

Mean LH pulse frequency also increased in relation to time of year and maximum pulse frequency occurred earlier $(P<0.001)$ in Group 1 than Group 2 (2 February and 10 April, respectively; Table 1$)$. Within each group, the increase in LH pulse frequency was associated with an increase in mean serum LH values although this trend was not apparent on all occasions studied. In this regard, mean LH pulse frequency in Group 1 increased between 1 December and 19 January in association with an increase in mean serum LH concentrations. However, between 15 December and 2 February mean $\mathrm{LH}$ pulse frequency increased approximately 5 -fold whereas mean serum $\mathrm{LH}$ concentrations remained unchanged $(P>0.05)$. In Group 2 , mean LH pulse frequency increased $(P<0.001)$ between 16 January and 10 April and was associated with an increase $(P<0.05)$ in mean serum 


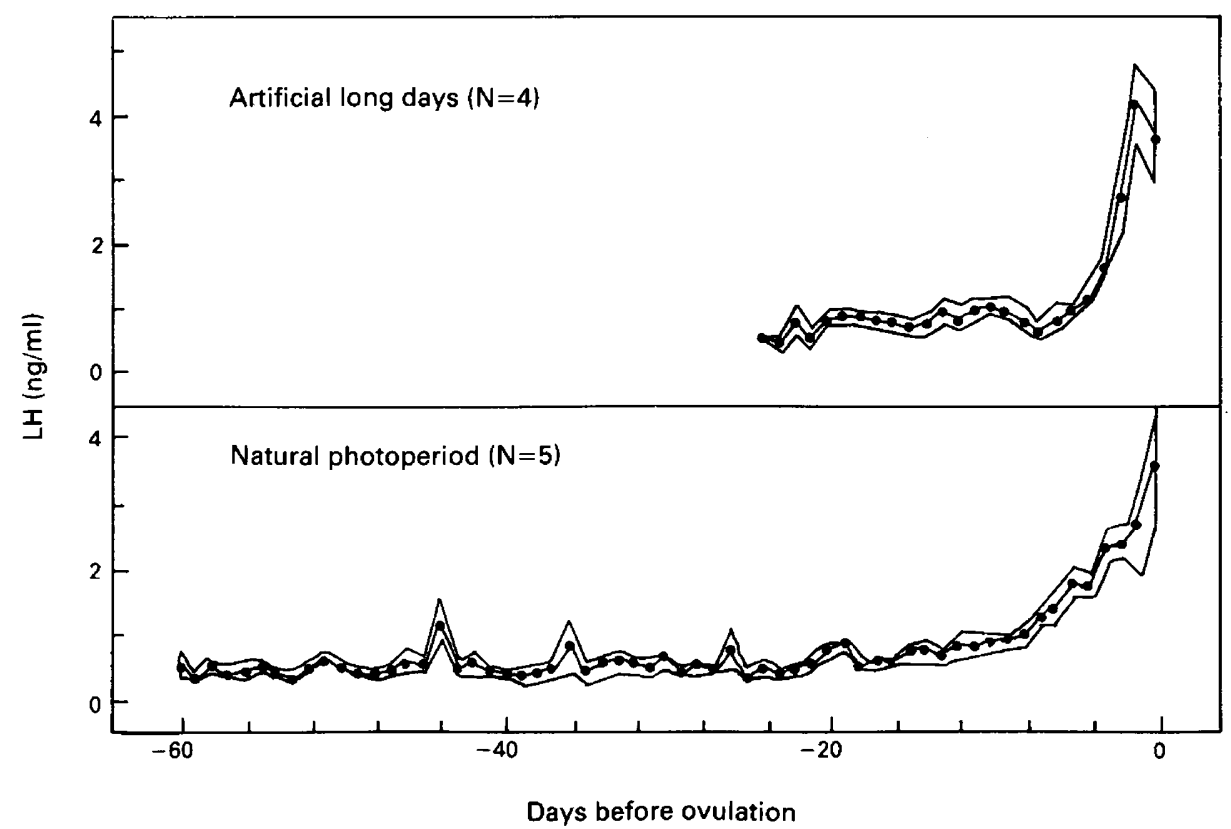

Fig. 1. Mean ( \pm s.e.m.) serum LH concentrations from samples collected daily for 24 days before ovulation in 4 mares (Group 1) exposed to abrupt increase in daylength, beginning 1 December (upper panel) and for 60 days in 5 mares (Group 2) exposed to natural photoperiodic conditions (lower panel).

Table 1. Changes in mean ( \pm s.e.m.) serum LH concentrations, LH pulse frequency and amplitude in mares in relation to time of year

\begin{tabular}{|c|c|c|c|c|c|}
\hline Group & Time of year & $\mathrm{N}^{*}$ & $\begin{array}{l}\text { Serum LH } \\
(\mathbf{n g} / \mathrm{ml})\end{array}$ & $\begin{array}{c}\text { No. of } \mathrm{LH} \\
\text { pulses per } 12 \mathrm{~h} \\
(12: 00-24: 00 \mathrm{~h})\end{array}$ & $\begin{array}{c}\text { LH pulse } \\
\text { amplitude (ng/ml) }\end{array}$ \\
\hline 1 & $\begin{array}{l}21 \text { Nov. } \\
1 \text { Dec. } \\
15 \text { Dec } \\
5 \text { Jan. } \\
19 \text { Jan. } \\
2 \text { Feb. } \\
17 \text { Feb. }\end{array}$ & $\begin{array}{l}0 / 4 \\
1 / 4 \\
2 / 4 \\
2 / 4 \\
3 / 4 \\
2 / 2 \\
0 / 1\end{array}$ & $\begin{array}{c}0.23 \pm 0.05 \\
0.19 \pm 0.09 \\
0.35 \pm 0.11 \\
0.36 \pm 0.12 \\
0.73 \pm 0.27 \\
0.47 \pm 0.07 \\
0.87\end{array}$ & $\begin{array}{c}0.00 \\
0.00 \\
0.50 \pm 0.28 \\
1.00 \pm 0.70 \\
1.25 \pm 0.63 \\
2.50 \pm 0.49 \\
0.00\end{array}$ & $\begin{array}{c}1.51 \dagger \\
2.49 \pm 1.24 \dagger \\
0.66 \pm 0.23 \\
0.70 \pm 0.06 \\
0.56 \pm 0.10\end{array}$ \\
\hline 2 & $\begin{array}{l}12 \mathrm{Dec} . \\
16 \mathrm{Jan} . \\
14 \mathrm{Feb} . \\
28 \mathrm{Feb} . \\
13 \mathrm{Mar} . \\
27 \mathrm{Mar} . \\
10 \mathrm{Apr} . \\
24 \mathrm{Apr} .\end{array}$ & $\begin{array}{l}2 / 5 \\
1 / 5 \\
3 / 5 \\
3 / 5 \\
4 / 5 \\
5 / 5 \\
3 / 3 \\
0 / 1\end{array}$ & $\begin{array}{c}0.49 \pm 0.20 \\
0.17 \pm 0.05 \\
0.55 \pm 0.16 \\
0.83 \pm 0.40 \\
0.46 \pm 0.06 \\
0.81 \pm 0.27 \\
0.92 \pm 0.25 \\
3.00\end{array}$ & $\begin{array}{c}0.60 \pm 0.39 \\
0.20 \pm 0.20 \\
0.60 \pm 0.24 \\
0.80 \pm 0.37 \\
1.00 \pm 0.31 \\
1.80 \pm 0.37 \\
3.33 \pm 0.66 \\
0.00\end{array}$ & $\begin{array}{c}1.43 \pm 0.28 \dagger \\
1.11 \dagger \\
2.39 \pm 0.32 \\
1.98 \pm 0.71 \\
1.39 \pm 0.54 \\
1.09 \pm 0.16 \\
0.70 \pm 0.08\end{array}$ \\
\hline
\end{tabular}

*Proportion of total number of mares exhibiting pulsatile LH release during $24-$ or $12-\mathrm{h}$ sample collection period.

$†$ †ean LH pulse amplitude includes all LH pulses observed during 24-h sample collection period. 
LH values (Table 1). However, as noted for Group 1 mares, a 5-fold rise in LH pulse frequency between 14 February and 10 April was unaccompanied by an increase $(P>0.05)$ in mean serum L.H concentrations (Table 1).

As shown in Table 1, there was in both groups a trend for a decrease in LH pulse amplitude in relation to time of year; however, insufficient data precluded further analysis of this observation.

\section{LH pattern in relation to time of ovulation}

Changes in mean serum LH concentrations and the pattern of LH secretion were assessed by blocking days before ovulation (Day $=0$ ) into sampling intervals of 10 days. This procedure resulted in 7 time periods ranging from 10-0 days (Period 1) to $>60$ days (Period 7) before ovulation; composite data for all 9 mares are depicted in Fig. 2.

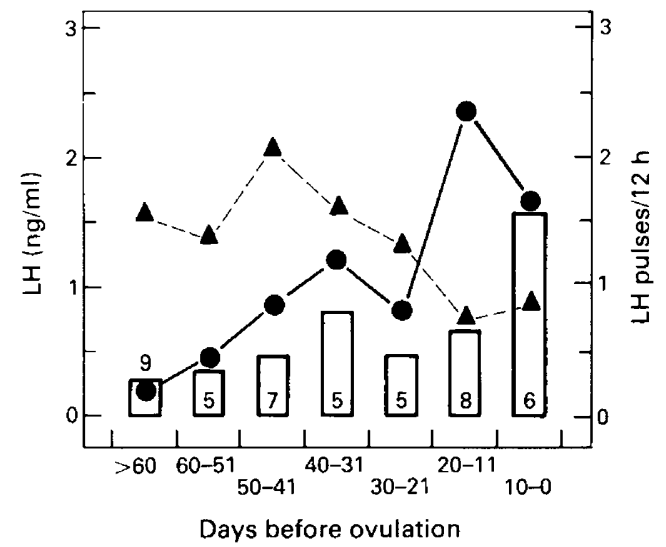

Fig. 2. Changes in mean serum LH concentrations (open bars), LH pulse frequency ( $)$ and amplitude $(\boldsymbol{\Delta})$ during the transition into the breeding season. Numbers at the bottom of the open bars indicate the number of mares. Data were normalized to the day of ovulation by using an arbitrary sampling interval of 10 days.

Mean serum LH concentrations increased $(P<0.001)$ between Periods 7 and 1 , from $0.29 \pm 0.05(\mathrm{~N}=9$ mares $)$ to $1.55 \pm 0.31 \mathrm{ng} / \mathrm{ml}(\mathrm{N}=6$ mares $)$. During this period, mean $\mathrm{LH}$ pulse frequency also increased $(P<0.001)$ from 0.19 pulses $/ 12 \mathrm{~h}$ in Period $7(\mathrm{~N}=9$, range $0-2$ pulses) to 2.37 pulses $/ 12 \mathrm{~h}$ in Period $2(\mathrm{~N}=8$, range $1-4$ pulses). However, between Periods 6 and 2 mean LH pulse frequency increased 6-fold but mean serum $\mathrm{LH}$ concentrations remained low and increased $(P<0.05)$ only during the final 10 days before ovulation (Period 1). Within Period 1 , mean LH pulse frequency apparently decreased but the observed frequency was not different from that in Period 2 before ovulation and may reflect the absence of identifiable LH pulses in 3 of 6 mares examined during this period. Finally, mean serum $\mathrm{LH}$ concentrations established from periods of frequent sample collection during 60 days before ovulation were similar $(P>0.05)$ to values determined in samples collected daily for 24 (Group 1) or 60 days (Group 2) before ovulation.

A significant $(P<0.02)$ reciprocal relationship was observed between LH pulse frequency and amplitude during the transition into the breeding season (Fig. 2). In general, LH pulse amplitude was $>1 \mathrm{ng} / \mathrm{ml}$ between Days $>60$ and $30-20$ before ovulation whereas 21 of $29 \mathrm{LH}$ pulses $(72 \%)$ observed during the final 20 days before ovulation were $<1 \mathrm{ng} / \mathrm{ml}$. 
Comparison of the periovulatory increase in serum $L H$ concentrations before the first and second ovulations of the breeding season

The interval between the first and second ovulations of the breeding season was not different $(P>0.05)$ between groups and averaged $22.5 \pm 0.8$ days $(\mathrm{N}=9$; range $17-26$ days). During a 10-day period preceding the respective ovulations, mean daily serum LH concentrations were not different between groups $(P>0 \cdot 05)$ and, therefore, results were pooled for comparisons between the first and second ovulation. As depicted in Fig. 3, the periovulatory rise in serum LH before the first ovulation was manifest as a linear increase $(P<0.001)$ with respect to time. In contrast, that preceding the second ovulation fitted a quadratic function $(P<0.001)$, indicating that mean serum LH concentrations increased more rapidly between Days 10 to 3 before the second than first ovulation and increased thereafter to a greater level $(P<0.05)$ on the day of ovulation $(9.50 \pm 1.71$ vs $3.56 \pm 1.78 \mathrm{ng} / \mathrm{ml}, \mathrm{N}=9$ ).

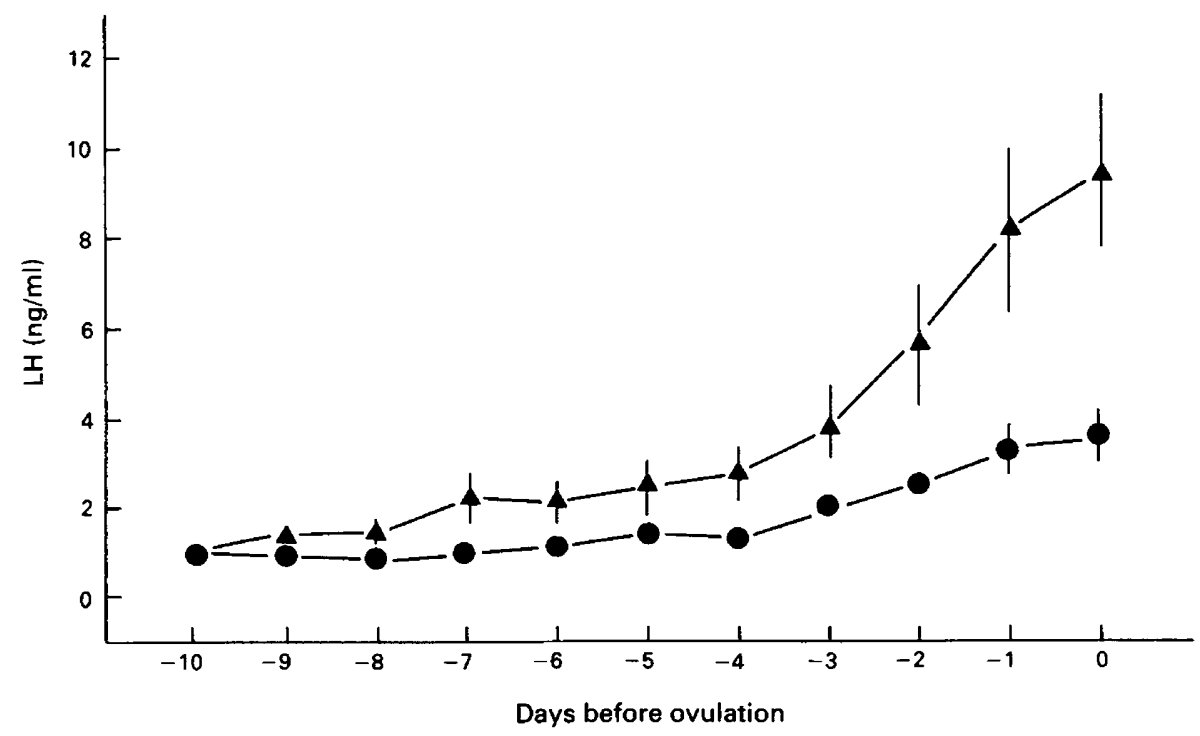

Fig. 3. Mean ( \pm s.e.m.) serum LH concentrations in 9 mares sampled daily during 10 days before the first $(\boldsymbol{O})$ and second $(\boldsymbol{\Delta})$ ovulations of the breeding season.

\section{Discussion}

The foregoing results demonstrate that, in the mare transition from seasonal anoestrus to the breeding season is associated with a photoperiod-induced, seasonal increase in the frequency of pulsatile LH secretion. A causal relationship between daylength and the observed increase in LH pulse frequency is suggested since an abrupt, artificial increase in daylength, applied during the winter months, advanced the timing of the increase in LH pulse frequency and the initiation of the breeding season, compared with that observed in mares maintained under natural photoperiodic conditions. The present results therefore suggest that a daylength-mediated seasonal increase in $\mathbf{L H}$ pulse frequency may play a role in the mechanisms governing the onset of the breeding season of this species. 
In Group 2 mares, from which blood samples were collected daily for 60 days before ovulation, mean daily serum LH values between 60 and 11 days before ovulation were similar to mean concentrations in frequent sample collection periods. This observation suggests that, during a 60 -day period before ovulation, blood samples collected daily appear to provide a reliable estimate of changes in mean serum LH concentrations. The present results therefore support earlier observations that in the mare the onset of the breeding season is not associated with a measurable increase in mean daily serum LH values until a few days before ovulation (Freedman et al., 1979; Turner et al., 1979). In addition, the present results extend these observations by providing evidence that the absence of a measurable increase in mean daily serum LH concentrations, until immediately before ovulation, is not a reflection of infrequent blood sample collection. However, in the present study daily blood samples were collected only from Group 2 mares for 60 days before ovulation. Furthermore, mean serum $\mathrm{LH}$ values determined in periods of frequent sample collection at $>60$ days were lower than values observed during the final 60 days before ovulation. It is possible, therefore, that a longer duration of daily blood sample collection might also yield evidence of a seasonal increase in serum LH concentrations.

Between 60 and 11 days before ovulation mean LH pulse frequency increased approximately 5-fold. That mean serum LH concentrations in both daily and frequently collected blood samples did not reflect this increase in LH pulse frequency was unexpected, since this finding contrasts with our previous observations for ovariectomized mares, at a comparable time of year (Fitzgerald et al., 1983). In ovariectomized mares a 4-fold increase in LH pulse frequency during the spring months was associated with a 9-fold increase in mean serum LH concentrations. One explanation to account for this discrepancy might be related to the amplitude of LH pulses. The present study demonstrates that in intact mares $\mathrm{LH}$ pulse amplitude is reciprocally related to $\mathrm{LH}$ pulse frequency whereas in ovariectomized mares the seasonal increase in $\mathrm{LH}$ pulse frequency during the spring months was not accompanied by a detectable change in LH pulse amplitude (Fitzgerald et al., 1983).

A reciprocal relationship between $\mathrm{LH}$ pulse frequency and amplitude has been observed in various species under different experimental conditions (Yen et al., 1974; Goodman \& Karsch, 1980; Rahe et al., 1980). Heretofore, such a relationship has not been reported for the mare and the mechanisms underlying this phenomenon remain to be elucidated. Studies with ovariectomized ewes, in which communication between the hypothalamus and pituitary gland has been interrupted (Clarke et al., 1984), or in rhesus monkeys bearing lesions of the arcuate nucleus (Wildt et al., 1981), indicate that high-frequency exogenous GnRH stimulation is associated with low LH pulse amplitude and vice versa. Furthermore, there is an upper limit to the ability of the pituitary gland to respond to pulsatile GnRH administration, at least in the rhesus monkey (Wildt et al., 1981). The observed reduction in LH pulse amplitude in mares entering the breeding season may therefore be caused by a decrease in pituitary responsiveness resulting from increased high-frequency $\mathrm{GnRH}$ stimulation. Additionally, the absence of LH pulses in some mares sampled a few days before ovulation may indicate that in the mare there may be an upper limit to the ability of the pituitary gland to respond to high-frequency GnRH stimulation. During the breeding season the frequency of hypothalamic GnRH release may increase to the extent that the pituitary gland is unable to respond by secreting discrete $\mathrm{LH}$ pulses. In support of this proposal, a non-pulsatile pattern of $\mathrm{LH}$ secretion is evident during the breeding season in ovariectomized mares (Fitzgerald et al., 1983) and in intact mares during the follicular phase of the oestrous cycle (Fitzgerald et al., 1985) when ovarian negative feedback effects on the hypothalamus-pituitary system are absent or minimal (Ginther, 1979). In ovariectomized ewes, a non-pulsatile pattern of LH secretion has been reported in a small number of animals when LH pulse frequency is maximal (Robinson et al., 1985).

Although the results of several studies suggest that pituitary gland responsiveness is reduced by high-frequency GnRH stimulation (Wildt et al., 1981; Clarke et al., 1984), in the mare we have observed that pituitary responsiveness to a single injection of $\mathrm{GnRH}$ is sometimes increased when serum $\mathrm{LH}$ concentrations are elevated and when, therefore, endogenous pulsatile GnRH stimulation 
might be anticipated to be frequent. Injection of ovariectomized mares with GnRH $(200 \mu \mathrm{g})$ during the spring months induces an elevation in serum LH concentrations comparable to the amplitude of endogenous $\mathrm{LH}$ pulses occurring at this time of year. In contrast, during the summer months, when serum LH values are maximally elevated but LH pulses cannot be identified, pituitary responsiveness to this $\mathrm{GnRH}$ dose is increased (B. P. Fitzgerald, unpublished). Whilst these results must be interpreted cautiously, since a single bolus injection may not be viewed as a physiological stimulus for LH release, it seems feasible in the light of these findings that the observed reduction in LH pulse amplitude during the transition period may reflect a decrease in GnRH pulse amplitude.

The present results confirm previous observations that the magnitude of the periovulatory $\mathrm{LH}$ rise preceding the first ovulation is lower than for subsequent ovulations during the breeding season (Oxender et al., 1977; Freedman et al., 1979). The mechanisms underlying this modification of the amplitude of the periovulatory LH rise are unknown although it is unlikely, as suggested earlier (Freedman et al., 1979), that this seasonal alteration is directly modulated by daylength. The present results demonstrate that serum $\mathrm{LH}$ concentrations associated with the first and second ovulations of the breeding season were similar in mares exposed to an abrupt artificial increase in daylength or maintained under natural photoperiodic conditions. An alternative mechanism might be an alteration in pituitary responsiveness during the breeding season, perhaps reflecting an increase in pituitary $\mathbf{L H}$ content as reported for mares during the transition from anoestrus to the breeding season (Hart et al., 1984).

Irrespective of the magnitude of the periovulatory LH rise preceding the first and subsequent ovulations of the breeding season, the duration of the first oestrous cycle was comparable to the known duration of oestrous cycles in the middle of the breeding season (i.e. about 22 days). This observation contrasts the sequence of events associated with the onset of oestrous cycles in the ewe. In a high proportion of ewes, the start of the breeding season may be characterized by one or more short luteal phases, as indicated by transient elevations in serum progesterone concentrations for 2-3-day periods before the occurrence of a luteal phase characteristic of the breeding season (Walton et al., 1977). In the ewe such transient elevations in progesterone, which also occur in other species at puberty or at the initiation of ovulatory cycles after a prolonged period of anovulation (Gonzalez-Padilla et al., 1975; Foster, 1977; Nass et al., 1979), may be caused by immaturity of the preovulatory follicle at the time of the preovulatory LH surge (Legan et al., 1985). Furthermore, it has been proposed that such brief elevations in serum progesterone, which are preceded by a preovulatory LH surge (I'Anson, 1985), may play an important role in the initiation of the breeding season by synchronizing the random anoestrous pattern of follicular development with an ensuing LH surge, thereby ensuring onset of a normal oestrous cycle (Legan et al., 1985). That this sequence of events does not occur in the mare, since serum progesterone concentrations increase only after the first ovulation of the breeding season (Oxender et al., 1977), suggests that in this species the follicle destined to ovulate is mature at the time of the first periovulatory $\mathrm{LH}$ rise, thereby ensuring an oestrous cycle of normal length. Furthermore, the observation that in a high proportion of mares large preovulatory size follicles develop and regress before the development of the follicle destined to ovulate suggests that this pattern of follicular development may function as a fail-safe mechanism to ensure complete follicular maturation at the time of the first periovulatory LH rise. Finally; the stimulus for the first periovulatory LH rise is unknown but the abrupt nature of this increase suggests a positive feedback stimulus provided by the ovaries.

Supported by the Grayson Foundation, Inc. The investigation reported in this paper (No. 86-4-33) was in connection with a project of the Kentucky Agriculture Experiment Station and is published with approval of the director.

We thank the staff of the University Farm for care of the animals; Dr T. M. Nett, Dr L. E. Reichert Jr, Dr H. Papkoff and Dr L. Edgerton for reagents used in the radioimmunoassays; and Mrs Lelia Garrison and Ms Kathy Williams for assistance with the radioimmunoassays. 


\section{References}

Baird, D.T. (1978) Pulsatile secretion of LH and ovarian estradiol during the follicular phase of the sheep estrous cycle. Biol. Reprod. 18, 359-364.

Clarke, I.J., Cummins, J.T., Findlay, J.K., Burman, K.J. \& Doughton, B.W. (1984) Effects on plasma luteinizing hormone and follicle stimulating hormone of varying the frequency and amplitude of gonadotropinreleasing hormone pulses in ovariectomized ewes with hypothalamo-pituitary disconnection. Neuroendocrinology 39, 214-221.

Dierschke, D.J., Bhattacharya, A.N., Atkinson, L.E. \& Knobil, E. (1970) Circhoral oscillations of plasma LH levels in the ovariectomized rhesus monkey. Endocrinology 87, 850-853.

Fitzgerald, B.P., I'Anson, H., Loy, R.G. \& Legan, S.J. (1983) Evidence that changes in LH pulse frequency may regulate the seasonal modulation of $\mathrm{LH}$ secretion in ovariectomized mares. J. Reprod. Fert. 69, 685-692.

Fitzgerald, B.P., l'Anson, H., Legan, S.J. \& Loy, R.G. (1985) Changes in patterns of luteinizing hormone secretion before and after the first ovulation in the postpartum mare. Biol. Reprod. 33, 316-323.

Foster, D.L. (1977) Luteinizing hormone and progesterone secretion during sexual maturation of the rhesus monkey: short luteal phases during the initial menstrual cycles. Biol. Reprod. 17, 584-590.

Freedman, L.J., Garcia, M.C. \& Ginther, O.J. (1979) Influence of photoperiod and ovaries on seasonal reproductive activity in mares. Biol. Reprod. 20, $567-574$.

Gallo, R.V. (1981) Pulsatile LH release during periods of low level LH secretion in the rat estrous cycle. Biol. Reprod. 24, 771-777.

Garcia, M.C., Greedman, L.J. \& Ginther, O.J. (1979) Interaction of seasonal and ovarian factors in the regulation of LH and FSH secretion in the mare. $J$. Reprod. Fert., Suppl. 27, 103-111.

Ginther, O.J. (1979) In Reproductive Biology of the Mare, Ch. 7, pp. 169-216. McNaughton and Gunn, Inc., Ann Arbor.

Gonzalez-Padilla, E., Wiltbank, J.N. \& Niswender, G.D. (1975) Puberty in beef heifers. I. The interrelationship between pituitary, hypothalamic and ovarian hormones. J. Anim. Sci. 40, 1091-1104.

Goodman, R.L. \& Karsch, F.J. (1980) Pulsatile secretion of luteinizing hormone: differential suppression by ovarian steroids. Endocrinology 107, 1286-1290.

Hart, P.J., Squires, E.L., Imel, K.J. \& Nett, T.M. (1984) Seasonal variation in hypothalamic content of gonadotropin-releasing hormone $(\mathrm{GnRH})$, pituitary receptors for $\mathrm{GnRH}$, and pituitary content of luteinizing hormone and follicle-stimulating hormone in the mare. Biol. Reprod. 30, 1055-1062.

I'Anson, H. (1985) More than one LH surge precedes the first full-length luteal phase of the breeding season in the ewe. Biol. Reprod. 32 (Suppl. 1), 267, Abstr.

Legan, S.J., I'Anson, H., Fitzgerald, B.P. \& Akaydin, M.S., Jr (1985) Importance of short luteal phases in the endocrine mechanism controlling initiation of estrous cycles in anestrous ewes. Endocrinology 117, 1530-1536.
Licht, P., Bona Gallo, A., Aggarwal, B.B., Farmer, S.W., Castelino, J.B. \& Papkoff, H. (1979) Biological and binding activities of equine pituitary gonadotrophins and pregnant mares serum gonadotrophin. J. Endocr. 83, 311-322.

Loy, R.G., Evans, M.J., Pemstein, R. \& Taylor, T.B. (1982) Effects of injected ovarian steroids on reproductive patterns and performance in post-partum mares. J. Reprod. Fert., Suppl. 32, 199-204.

Nass, T.E., Dierschke, D.J., Clarke, J.R., Meller, P.A. \& Schillo, K.K. (1979) Luteal phase deficiencies in peripubertal rhesus monkeys: Mechanistic considerations. In Ovarian Follicular and Corpus Luteum Function, pp. 519-525, Eds C. P. Channing, J. M. Marsh \& W. A. Sadler. Plenum Press, New York.

Oxender, W.D., Noden, P.A. \& Hafs, H.D. (1977) Estrus, ovulation and serum progesterone, estradiol and $\mathrm{LH}$ concentrations in mares after an increased photoperiod during winter. Am. J. vet. Res. 38, 203-207.

Pineda, M.H. \& Ginther, O.J. (1972) Inhibition of estrus and ovulation in mares treated with an antiserum against an equine pituitary fraction. Am. J. vet. Res. 33, 1775-1780.

Rahe, C.H., Owens, R.E., Fleeger, J.L., Newton, H.J. \& Harmes, P.G. (I980) Pattern of plasma luteinizing hormone in the cyclic cow: dependence upon the period of the cycle. Endocrinology 107, 498-503.

Robinson, J.E., Radford, H.M. \& Karsch, F.J. (1985) Seasonal changes in pulsatile luteinizing hormone (LH) secretion in the ewe: relationship of frequency of LH pulses to day length and response to estradiol negative feedback. Biol. Reprod. 33, 324-334.

SAS Institute Inc. (1985) SAS User's Guide: Version 5 Edition. SAS Institute Inc., Cary, NC.

Sharp, D.C. \& Ginther, O.J. (1975) Stimulation of follicular activity and estrous behavior in anestrous mares with light and temperature. J. Anim. Sci. 41, $1368-1372$

Turner, D.D., Garcia, M.C. \& Ginther, O.J. (1979) Follicular and gonadotrophic changes throughout the year in pony mares. Am. J. vet. Res. 40, 1694-1700.

Walton, J.S., McNeilly, J.R., McNeilly, A.S. \& Cunningham, F.J. (1977) Changes in concentrations of follicle-stimulating hormone, luteinizing hormone, prolactin and progesterone in the plasma of ewes during the transition from anoestrus to breeding activity. J. Endocr. 75, 127-136.

Wildt, L., Hausler, A., Marshall, G., Hutchinson, J.S., Plant, T.M. \& Knobil, E. (1981) Frequency and amplitude modulation of gonadotropin-releasing hormone stimulation of gonadotropin secretion in the rhesus monkey. Endocrinology 109, 376-385.

Yen, S.S.C., Vanderberg, G., Tsai, C.C. \& Parker, D.C. (1974) Ultradian fluctuations of gonadotropins. In Biorhythms and Human Reproduction, pp. 203-218. Eds M. Ferin, F. Galberg, R. M. Richart, R. L. Vande Wiele. Wiley, New York.

Received 30 June 1986 